\title{
Hoe gezondheidsbeleid de toewijding van werknemers beïnvloedt
}

\author{
Jan Fekke Ybema en Maartje Bakhuys Roozeboom*
}

In een longitudinaal onderzoek onder 1.013 werknemers met drie jaarlijkse metingen is nagegaan of het gezondheidsbeleid van werkgevers invloed heeft op de toewijding van werknemers. Bovendien is nagegaan of gezondheidsbeleid bijdraagt aan autonomie, sociale steun (van leidinggevende, van collega's) en rechtvaardigheid in de organisatie (procedureel, distributief) en of het effect van gezondheidsbeleid op toewijding via deze hulpbronnen loopt. Uit het onderzoek blijkt dat gezondheidsbeleid op T1 bijdraagt aan hogere toewijding op T3, na correctie voor toewijding op T1. Bovendien blijkt dat gezondheidsbeleid geen invloed heeft op autonomie, maar wel leidt tot meer sociale steun van de leidinggevende en collega's en tot hogere procedurele en distributieve rechtvaardigheid op T2 na correctie voor deze hulpbronnen op T1. De effecten van gezondheidsbeleid op toewijding worden deels gemedieerd door meer sociale steun van de leidinggevende en hogere procedurele rechtvaardigheid. Dit betekent dat werkgevers zouden moeten investeren in gezondheidsbeleid om de hulpbronnen van werknemers te verhogen en hun toewijding te bevorderen.

\section{Inleiding}

De gezondheid en vitaliteit van werknemers is een belangrijk thema voor werkgevers. Veel werkgevers zijn bereid te investeren in de vitaliteit van werknemers, omdat dit kan leiden tot minder verzuim, verhoging van het werkvermogen en de productiviteit van werknemers en een beter sociaal klimaat (Johanson, Ahonen \& Roslender, 2007; Zwetsloot \& Van Scheppingen, 2007). Dit artikel is gericht op de effecten van gezondheidsbeleid van organisaties op de toewijding van werknemers. We onderzoeken in een longitudinaal onderzoek onder werknemers ten eerste of gezondheidsbeleid van de organisatie de toewijding van werknemers vergroot. Indien dat het geval is, gaan we ten tweede na hoe dit effect tot stand komt en of de invloed van gezondheidsbeleid op de toewijding van werknemers het gevolg is van meer bulpbronnen in het werk.

* De auteurs zijn werkzaam bij TNO Kwaliteit van Leven | Arbeid.

Correspondentieadres: Dr. J.F. Ybema, TNO Kwaliteit van Leven | Arbeid, Postbus 718, 2130 AS Hoofddorp, tel. 023-5549559, e-mail jan_fekke.ybema@tno.nl. 


\subsection{Gezondheidsbeleid}

Bedrijven kunnen allerhande vormen van gezondheidsbeleid voeren. Daarbij wordt vaak onderscheid gemaakt tussen maatregelen die de gezondheid van individuen bevorderen (GVO) en maatregelen die gericht zijn op de veiligheid en gezondheid van het werk (OSH) (Sorensen \& Barbeau, 2004; Goetzel, Ozminkowski, Bowen \& Tabrizi, 2008). Bedrijven zijn wettelijk verplicht om te zorgen voor een veilige werkomgeving en daarnaast zijn er veelal sectorale afspraken over de fysieke en psychosociale arbeidsomstandigheden. Bedrijven die meer investeren in de gezondheid van werknemers, doen dat vooral door gezondheidsbevorderende maatregelen. Zo worden werknemers in sommige bedrijven gestimuleerd om deel te nemen aan fitnessprogramma's, of wordt het lunchaanbod in kantines aangepast om een gezonde eetstijl aan te moedigen. In andere bedrijven worden werknemers aangemoedigd om te fietsen naar het werk of deel te nemen aan het zogenaamde 'lunchwandelen' (Visser \&Witte, 2005). De laatste jaren is echter de behoefte ontstaan aan een meer integrale benadering van gezondheidsmanagement, waarin zowel aandacht is voor het individuele gedrag als voor de arbeidsomstandigheden, maar waarin ook aandacht is voor bijvoorbeeld de organisatiecultuur (Goetzel, Shechter, Marmet, Tabrizi \& Roemer, 2007).

In Nederland is een dergelijke integrale benadering geïntroduceerd door Zwetsloot en collega's (Gründemann, Piek, Zwetsloot, Van Scheppingen, Raaijmakers et al., 2003; Zwetsloot \& Pot, 2004; Zwetsloot \& Van Scheppingen, 2007) onder de term Integraal Gezondheidsmanagement (IGM). Het integrale karakter van IGM betekent dat gezondheid niet los gezien moet worden van de bedrijfsvoering, maar dat gezondheid bij alle strategische beslissingen van het bedrijf een rol speelt. Bij IGM wordt bovendien niet alleen aandacht besteed aan de gezondheid van werknemers, maar ook aan de gezondheid van klanten en omwonenden.

Een belangrijk kenmerk van IGM is dat het zich niet alleen richt op het voorkómen van gezondheidsproblemen en het beperken van ziekte(kosten), maar vooral op het bevorderen van gezondheid en welzijn van alle werknemers. IGM wordt dan ook gezien als investering in werknemers (Zwetsloot \& Pot, 2004). Naast curatie en preventie, staat in dit beleid vooral 'amplitie' centraal. Met amplitie worden interventies bedoeld die zijn gericht op het bevorderen van positieve toestanden bij werknemers, zoals gezondheid, welbevinden en bevlogenheid (Ouweneel, Schaufeli \& LeBlanc, 2009).

\subsection{Toewijding}

Bevlogenheid in het werk heeft betrekking op 'een positieve, bevredigende, werkgerelateerde gemoedstoestand' (Schaufeli \& Bakker, 2004). Een bevlogen werknemer kenmerkt zich door vitaliteit, absorptie en toewijding. Vitaliteit heeft betrekking op het hebben van veel energie, zich sterk, fit en onvermoeibaar voelen en het hebben van een grote mentale veerkracht en doorzettingsvermogen. Absorptie betekent het op plezierige wijze opgaan in het werk. Toewijding heeft betrekking op een sterke betrokkenheid bij het werk, waarbij werknemers het werk als nuttig en zinvol ervaren en het werk gevoelens van trots en enthousiasme oproept (Schaufeli \& Bakker, 200I, p. 245). In dit artikel richten we ons op toewijding, als onderdeel van bevlogenheid. 
Aangezien gezondheidsbeleid steeds meer gericht is op amplitie, onderzoeken wij in deze studie of gezondheidsbeleid van invloed is op de toewijding van werknemers.

Hypothese r: Gezondheidsbeleid vergroot de toewijding van werknemers.

In dit onderzoek zijn we niet alleen geïnteresseerd in de vraag of gezondheidsbeleid de toewijding van werknemers vergroot, maar - indien dat het geval is - ook in de vraag hoe gezondheidsbeleid de toewijding van werknemers vergroot. Deze hoe-vraag betreft de mogelijke mediatoren van het veronderstelde effect van gezondheidsbeleid op toewijding. Aangezien IGM zich niet alleen richt op aspecten die van invloed zijn op het voorkomen van gezondheidsproblemen van werknemers (zoals arbeidsomstandigheden en HRM), maar vooral ook op aspecten die het welbevinden van werknemers vergroten (zoals het sociale klimaat en de organisatiecultuur), veronderstellen

356 wij dat gezondheidsbeleid bijdraagt aan een toename van hulpbronnen (resources) in het werk. In dit onderzoek richten we ons op drie hulpbronnen waarvan wij veronderstellen dat gezondheidsbeleid er een positieve invloed op heeft en waarvan bekend is dat ze positieve effecten hebben op het welbevinden van werknemers. Dit zijn autonomie, sociale steun en rechtvaardigheid.

\subsection{Hulpbronnen}

De term hulpbronnen (resources) is afkomstig uit het Conservation of Resourcesmodel (COR-model) (Hobfoll, r989; Halbesleben, 2006). Dit model stelt dat mensen trachten hulpbronnen te verzamelen en te behouden. Hulpbronnen kunnen bijvoorbeeld betrekking hebben op het werk (zekerheid, salaris, autonomie), op sociale contacten (sociale steun, prestige) of op persoonlijke eigenschappen (zelfwaardering, veerkracht, zelfeffectiviteit). Het Job Demands-Resources-model (JD-R-model) (Demerouti, Bakker, Nachreiner \& Schaufeli, 20or) is een psychosociaal werkstressmodel en bouwt voort op het COR-model. Het JD-R-model beschrijft twee processen die parallel aan elkaar plaatsvinden. In het eerste proces leiden zware taakeisen in het werk tot aantasting van de energiereserves van werknemers en op de lange termijn tot burnout. Het tweede proces veronderstelt dat hulpbronnen in het werk (zoals autonomie en sociale steun) bijdragen aan de motivatie en bevlogenheid van werknemers. In dit artikel richten we ons uitsluitend op dit tweede proces.

Gezondheidsbeleid en hulpbronnen. Wij kennen geen onderzoeken die rechtstreeks gericht zijn op de relatie tussen gezondheidsbeleid en hulpbronnen. Wel wordt in de recente literatuur over gezondheidsbeleid benadrukt dat dergelijk beleid van werkgevers gericht moet zijn op het verbeteren van het sociale klimaat (Johanson et al., 2007) en op participatie van werknemers (Aust \& Ducki, 2004; Shain \& Kramer, 2004). Bovendien kan gezondheidsbeleid bijdragen aan een gezonde organisatiecultuur waarin op een zorgvuldige wijze met mensen wordt omgegaan, waardoor werknemers zich meer gewaardeerd en rechtvaardiger bejegend voelen (Hasle \& Møller, 2007).

Het lijkt daarom waarschijnlijk dat bij het implementeren van dergelijk beleid de hulpbronnen van werknemers toenemen. In dit onderzoek richten we ons op autonomie, sociale steun en rechtvaardigheid. Autonomie betreft de mate waarin werknemers zelf invloed hebben op de inhoud en volgorde van hun werkzaamheden. Sociale 
steun van leidinggevende en collega's zijn aspecten van het sociale klimaat op het werk. Ten slotte beschouwen we procedurele rechtvaardigheid en distributieve rechtvaardigheid als hulpbronnen die het welbevinden kunnen vergroten. Procedurele rechtvaardigheid betreft de mate waarin er bij beslissingen in de organisatie rekening gehouden wordt met de belangen en wensen van werknemers. Distributieve rechtvaardigheid heeft betrekking op de verdeling van uitkomsten, bijvoorbeeld de waardering die een werknemer krijgt of het salaris dat iemand verdient.

Hypothese 2: Gezondheidsbeleid vergroot de hulpbronnen autonomie, sociale steun en rechtvaardigheid in het werk.

Hulpbronnen en toewijding. Er is inmiddels een aanzienlijke hoeveelheid literatuur opgebouwd, die de positieve effecten van hulpbronnen op de bevlogenheid van werknemers laat zien. Onderzoek van Mauno, Kinnunen en Ruokolainen (2007) wijst uit dat autonomie een belangrijke voorspeller is van toewijding en van de beide andere dimensies van bevlogenheid. Ook andere onderzoeken vinden een positieve relatie tussen autonomie en bevlogenheid (Demerouti et al., 20or; Hakanen, Bakker \& Schaufeli, 2006; Saks, 2006; Xanthopoulou, Bakker, Demerouti \& Schaufeli, 2007). Sociale steun van leidinggevende en collega's zijn sociale hulpbronnen in het werk die een belangrijke rol innemen in het COR-model (Halbesleben, 2006). Talloze studies laten zien dat sociale steun het welbevinden van werknemers kan bevorderen en de negatieve effecten van stressvolle werkomstandigheden kan beperken (Cohen \& Wills, 1985; Hakanen et al., 2006; Saks, 2006; Xanthopoulou et al., 2007). Rechtvaardigheid in organisaties is een belangrijke determinant van de gezondheid en het welbevinden van werknemers (voor een overzicht, zie Greenberg \& Colquitt, 2005). Voor zover wij weten, is de relatie tussen rechtvaardigheid en toewijding niet eerder onderzocht, maar wel is aangetoond dat rechtvaardigheid op het werk leidt tot minder burnout en meer tevredenheid met het werk (Ybema, 2007). De Boer, Bakker, Syroit en Schaufeli (2002) lieten bovendien zien dat procedurele rechtvaardigheid op het werk bijdraagt aan affectieve betrokkenheid bij het werk.

Hypothese 3: De hulpbronnen autonomie, sociale steun en rechtvaardigheid vergroten de toewijding van werknemers.

Hulpbronnen als mediatoren. In dit onderzoek gaan we na of gezondheidsbeleid bijdraagt aan hogere toewijding van werknemers. Zoals we eerder aangaven, zijn we in dit onderzoek niet alleen geïnteresseerd in de vraag of gezondheidsbeleid de toewijding van werknemers vergroot, maar - indien dat het geval is - ook in de vraag hoe gezondheidsbeleid de toewijding van werknemers vergroot. Hierbij onderzoeken we of de hulpbronnen autonomie, sociale steun en rechtvaardigheid optreden als mediator van het effect van gezondheidsbeleid op toewijding.

Hypothese 4: Het effect van gezondheidsbeleid op toewijding kan worden verklaard doordat gezondheidsbeleid leidt tot meer hulpbronnen in het werk en deze hulpbronnen de toewijding van werknemers vergroten. 


\section{Methode}

\subsection{Onderzoeksopzet en steekproef}

Dit onderzoek maakt gebruik van de Cohortstudie Arbeid, Verzuim en Gezondheid (AVG) (Ybema, Sanders \& De Vroome, 2006). De AVG is een longitudinaal onderzoek met drie jaarlijkse metingen onder een steekproef van Nederlandse werknemers. De steekproef voor de AVG is getrokken uit het online respondentenpanel van Intomart/GfK. Uit dit panel is in 2004 een steekproef getrokken van 3.Ioo personen die werkzaam zijn als werknemer. De data zijn verzameld middels internetenquêtes. Bij de eerste meting in mei 2004 vulden 2.502 werknemers (8I\% respons) de vragenlijst volledig in. Deze groep van 2.502 personen is opnieuw benaderd in mei 2005 en in mei 2006. Bij de tweede meting was de respons 1.934 personen $(77 \%)$ en bij de derde meting I.92I personen (77\%).

358 Van I.597 respondenten waren bruikbare gegevens beschikbaar op alle drie de metingen. Respondenten die tussen de eerste en derde meting van werkgever waren veranderd, zijn in dit onderzoek uitgesloten $\left(\mathrm{N}=35^{2}\right)$. Daarnaast zijn respondenten uitgesloten die missende waarden hadden op één of meer van de variabelen die in dit onderzoek worden gebruikt $(\mathrm{N}=232)$, zodat alle analyses uitgevoerd werden op dezelfde groep respondenten. Van de overgebleven $\mathrm{r}$.0I3 respondenten was $60 \%$ man en de gemiddelde leeftijd bedroeg 4I jaar $(S D=9.4)$. Het opleidingsniveau was laag voor $19 \%$ van de respondenten (minder dan I\% geen opleiding; $3 \%$ basisonderwijs; I6\% vmbo/mavo), middelhoog voor $40 \%$ van de respondenten ( $27 \% \mathrm{mbo}$; $12 \%$ havo/ vwo), en hoog voor $42 \%$ van de respondenten ( $31 \%$ hbo; II $\%$ universiteit). Ten tijde van de eerste meting hadden de meeste respondenten (90\%) een vaste baan bij hun huidige werkgever. De overige ro\% had een tijdelijk contract of was uitzend- of oproepkracht. Zesendertig procent van de respondenten werkte parttime en had een contract van 32 uur per week of minder. Van de respondenten had 10\% een leidinggevende functie en nog eens $25 \%$ van de respondenten gaf leiding aan andere werknemers als onderdeel van hun taken. De steekproef was in grote lijnen representatief voor werknemers in Nederland, waarbij alle grotere beroepgroepen en sectoren vertegenwoordigd waren. De steekproef omvat echter wel minder jongere werknemers, minder laag opgeleide werknemers en minder allochtonen dan de populatie van werknemers in Nederland.

\subsection{Onderzoeksvariabelen}

De vragenlijst bevat een groot aantal vragen over diverse onderwerpen: de persoon, de werkkring, leefstijl, gezondheid, psychisch welzijn en werkbeleving, organisatiecultuur, arbeidsomstandigheden, verzuim, contacten met zorgverleners en werkgeversbeleid. Bij iedere jaarlijkse meting is vrijwel dezelfde vragenlijst afgenomen. In het huidige onderzoek wordt gebruikgemaakt van de volgende onderwerpen: demografische variabelen (geslacht, leeftijd en opleidingsniveau), gezondheidsbeleid, autonomie, sociale steun (van leidinggevende, van collega's), rechtvaardigheid (distributieve en procedurele rechtvaardigheid) en toewijding.

Demografische variabelen. In de vragenlijst is gevraagd naar het geslacht van de respondent $(\mathrm{I}=$ man, 2 = vrouw $)$, naar het geboortejaar, op basis waarvan de leeftijd in jaren is berekend ten tijde van de eerste meting, en naar het opleidingsniveau ( $\mathrm{I}=$ 
geen opleiding afgemaakt, 2 = basisonderwijs, $3=$ vmbo $/$ mavo, $4=\mathrm{mbo}, 5=$ havo $/$ vwo, 6 = hbo en 7 = wo).

Gezondheidsbeleid. Gezondheidsbeleid is gemeten met een schaal die is gebaseerd op de literatuur over Integraal Gezondheidsmanagement (IGM) (Gründemann et al., 2003). De schaal bevat tien stellingen over de mate waarin gezondheid centraal staat in het beleid van het bedrijf en de mate waarin organisaties gezondheid hebben geïntegreerd in de bedrijfsvoering. Bijvoorbeeld: 'In het bedrijf/de vestiging waar ik werk, is gezondheid een belangrijk onderdeel van de beleidsvoering' met als antwoordcategorieën: $\mathrm{I}=$ helemaal mee oneens, $2=$ mee oneens, $3=$ noch mee oneens noch mee eens, $4=$ mee eens en $5=$ helemaal mee eens. In tabel I staan de vragen en de gemiddelde scores op ieder item weergegeven. De schaal heeft een goede betrouwbaarheid (Cronbachs $\alpha=.90$ ).

Tabel 1 De items en gemiddelde scores per item van schaal voor gezondheidsbeleid op T1

\begin{tabular}{lcc}
\hline & T1 \\
\hline In het bedrijflde vestiging waar ik werk: & M & SD \\
\hline Is gezondheid een belangrijk onderdeel van de bedrijfsvoering & 3.38 & 0.97 \\
$\begin{array}{l}\text { Worden voldoende inspanningen geleverd om de gezondheid van } \\
\text { medewerkers te beschermen }\end{array}$ & 3.43 & 0.95 \\
$\begin{array}{l}\text { ls elke werkplek gezond en veilig ontworpen } \\
\text { Wordt bij de aanschaf van materialen voldoende rekening gehouden met }\end{array}$ & 3.16 & 1.02 \\
$\begin{array}{l}\text { de gezondheid van medewerkers } \\
\text { Vinden alle medewerkers gezond en veilig werkgedrag belangrijk }\end{array}$ & 3.58 & 0.99 \\
$\begin{array}{l}\text { Wordt goede voorlichting gegeven over het gezondheidsbeleid } \\
\text { Worden initiatieven op het terrein van sport, cultuur, milieu, gezondheid }\end{array}$ & 3.14 & 1.01 \\
$\begin{array}{l}\text { en welzijn actief ondersteund } \\
\text { Wordt actief beleid gevoerd om de gezondheid van medewerkers en }\end{array}$ & 2.72 & 1.11 \\
gezinsleden van medewerkers te bevorderen & & 1.04 \\
$\begin{array}{l}\text { Worden gezonde en milieuvriendelijke grondstoffen producten/diensten } \\
\text { geproduceerd/geleverd }\end{array}$ & 2.97 & 1.03 \\
$\begin{array}{l}\text { Worden producten gemaakt of diensten geleverd die bijdragen aan de } \\
\text { gezondheid van onze klanten }\end{array}$ & 3.01 & 1.14 \\
\hline
\end{tabular}

Autonomie. Autonomie is gemeten met behulp van vier items die afkomstig zijn van de schaal decision latitude van Karasek et al. (1998). Een voorbeelditem is: 'Beslist u zelf wanneer u een takk uitvoert?' De antwoordcategorieën zijn: $\mathrm{I}=$ nooit, $2=$ soms, $3=$ vaak en $4=$ altijd. De betrouwbaarheid van de schaal is goed (Cronbachs $\alpha=.8 \mathrm{I})$.

Sociale steun. Sociale steun van de leidinggevende is gemeten met vier items die zijn ontleend aan de schaal voor supervisory support van Karasek et al. (1998). Een voorbeelditem is: 'Mijn chef heeft doorgaans oog voor het welzijn van de medewerkers.' Sociale steun van collega's is gemeten met vier items uit de schaal voor co-worker support van Karasek et al. (I998). Een voorbeelditem is: 'Collega's helpen mij door- 
gaans om het werk gedaan te krijgen.' De antwoordcategorieën van beide schalen variëren van $\mathrm{I}=$ helemaal mee oneens, tot $5=$ helemaal mee eens. De betrouwbaarheid van de schalen is goed voor zowel steun van leidinggevende (Cronbachs $\alpha=.89$ ) als voor steun van collega's (Cronbachs $\alpha=.82$ ).

Rechtvaardigheid. De vragen voor procedurele en distributieve rechtvaardigheid zijn overgenomen van De Boer et al. (2002). Procedurele rechtvaardigheid is gemeten met vier vragen die vooral betrekking hebben op structurele aspecten van procedurele rechtvaardigheid (Cropanzano \& Greenberg, I997; De Boer et al., 2002). Een voorbeelditem is: 'Alle werknemers worden op een gelijke manier behandeld', met antwoordcategorieën variërend van $\mathrm{I}=$ helemaal mee oneens, tot $5=$ helemaal mee eens. Deze schaal heeft een goede betrouwbaarheid (Cronbachs $\alpha=.87$ ). Distributieve rechtvaardigheid is gemeten met zes vragen die direct aansluiten bij de billijkheidstheorie van Adams (1965). Drie vragen hadden betrekking op de rechtvaardigheid 360 van het salaris. Een voorbeelditem is: 'Wat vindt u van uw salaris ... als u uw inzet op het werk vergelijkt met die van uw collega's?' Drie vergelijkbare vragen hadden betrekking op de waardering die men krijgt. Een voorbeeld is de vraag 'Wat vindt $u$ van de waardering die u krijgt ... als u bekijkt hoeveel taken $u$ heeft in vergelijking met uw collega's?' Antwoordcategorieën waren: $\mathrm{I}=$ veel te weinig waardering, 2 = iets te weinig, 3 = precies goed, 4 = iets te veel, $5=$ veel te veel waardering. Deze antwoorden werden als volgt gehercodeerd om een bruikbare schaal voor een distributieve rechtvaardigheid te krijgen: 3 = precies goed, 2 = iets te weinig/iets te veel, $\mathrm{I}=$ veel te weinig/veel te veel. De gehercodeerde vragen leverden een betrouwbare schaal op voor distributieve rechtvaardigheid (Cronbachs $\alpha=.86$ ).

Toewijding. Toewijding is gemeten met een subschaal van de Werkbelevingslijst (UBES) (Schaufeli, Salanova, Gonzáles-Romá \& Bakker, 2002) die bevlogenheid meet. De oorspronkelijke schaal bevat drie subschalen, die vitaliteit, toewijding en absorptie worden genoemd. Gezien de lengte van de vragenlijst is alleen de subschaal toewijding gemeten in dit onderzoek met vier items. Een voorbeelditem is 'Mijn werk inspireert me', met als antwoordcategorieën: $\mathrm{I}=$ nooit, $2=$ zelden, $3=$ soms wel $/ \mathrm{soms}$ niet, 4 = vaak en 5 = altijd. De betrouwbaarheid van deze schaal is goed (Cronbachs $\alpha=.90)$.

\subsection{Analyses}

De analyses voor dit onderzoek zijn gedaan met behulp van SPSS I4. Om te onderzoeken of gezondheidsbeleid (op $\mathrm{T}_{\mathrm{I}}$ ) van invloed is op toewijding (op $\mathrm{T}_{3}$ ) en om te onderzoeken of autonomie, sociale steun en rechtvaardigheid (op $\mathrm{T}_{2}$ ) hierbij een mediërende rol spelen zijn hiërarchische regressieanalyses uitgevoerd. In deze regressies wordt zowel gecorrigeerd voor eerdere metingen van de afhankelijke variabele (toewijding) als voor eerdere metingen van de mediatoren (autonomie, sociale steun, rechtvaardigheid) (Cole \& Maxwell, 2003). Om te onderzoeken of er sprake is van mediërende effecten van de hulpbronnen wordt gebruikgemaakt van de Sobel-test (Baron \& Kenny, I986; Cole \& Maxwell, 2003). In al deze analyses worden het geslacht, de leeftijd en het opleidingsniveau van de respondenten meegenomen om te corrigeren voor hun samenhang met toewijding (Schaufeli \& Bakker, 2004). 


\section{Resultaten}

\subsection{Beschrijvende analyses}

In tabel 2 zijn de gemiddelde waarden en standaarddeviaties en de correlaties tussen de onderzoeksvariabelen weergegeven. Uit de tabel blijkt dat toewijding op $T_{1}$ en toewijding op $\mathrm{T}_{3}$ onderling sterk samenhangen. Blijkbaar is er sprake van een aanzienlijke stabiliteit in toewijding. Verder valt op dat de toewijding op $T_{r}$ iets hoger is dan op $\mathrm{T}_{3}, t$ (IоI2) $=3.70, p<$.oor. Mogelijk is dit het gevolg van regressie naar het midden. Werknemers die van baan veranderd zijn, zijn uitgesloten uit dit onderzoek $(n=352)$ en zij waren gemiddeld genomen aanzienlijk minder toegewijd $(M=3.57)$ dan de werknemers die wel zijn opgenomen in dit onderzoek $(M=3.90), t\left(\mathrm{r}_{3} 63\right)=6.68$, $p<$.oor. Verder blijkt uit tabel 2 dat gezondheidsbeleid op Tr samenhangt met hogere toewijding op $\mathrm{T}_{\mathrm{r}}$ en op $\mathrm{T}_{3}$ en samenhangt met hogere autonomie, meer sociale steun van leidinggevende en collega's, meer procedurele en meer distributieve rechtvaardigheid op $T_{1}$ en $T_{2}$. Ten slotte valt op dat er op beide metingen een hoge samenhang is tussen sociale steun van de leidinggevende en procedurele rechtvaardigheid. Mogelijk wordt de beoordeling van de procedures in een bedrijf vooral gestuurd door de directe ervaringen met de eigen leidinggevende. Een andere verklaring is dat sociale steun van de leidinggevende en procedurele rechtvaardigheid beide indicaties zijn van een goede organisatiecultuur.

\subsection{Effecten van gezondheidsbeleid op hulpbronnen}

Hypothese 2 stelt dat gezondheidsbeleid bijdraagt aan verbeteringen in de hulpbronnen op het werk. Om dit te onderzoeken is een vijftal regressieanalyses uitgevoerd. In de analyses zijn de afhankelijke variabelen respectievelijk autonomie, sociale steun van leidinggevende, sociale steun van collega's, procedurele rechtvaardigheid en distributieve rechtvaardigheid op $T_{2}$. De onafhankelijke variabelen in elke analyse zijn geslacht, leeftijd, opleidingsniveau, de betreffende hulpbron op Ti en gezondheidsbeleid op Ti. Hierbij wordt dus gecorrigeerd voor de afhankelijke variabele (hulpbron) op de eerste meting, waardoor de bijdrage van gezondheidsbeleid kan worden geïnterpreteerd als het effect van gezondheidsbeleid op verandering van de betreffende hulpbron. De resultaten van deze analyses zijn weergegeven in tabel 3. Uit de tabel blijkt dat gezondheidsbeleid niet van invloed is op de autonomie van werknemers, maar wel leidt tot meer sociale steun van leidinggevende, meer sociale steun van collega's en meer procedurele en distributieve rechtvaardigheid in de organisatie. Hypothese 2 wordt dus niet bevestigd voor autonomie, maar wel voor sociale steun en rechtvaardigheid: gezondheidsbeleid draagt bij aan verbetering van de hulpbronnen in het werk. Uit tabel 3 blijkt verder dat vrouwen een sterkere toename in distributieve rechtvaardigheid ervaren dan mannen. Daarnaast blijkt dat een hoog opleidingsniveau bijdraagt aan hogere autonomie en de hogere distributieve en procedurele rechtvaardigheid. 


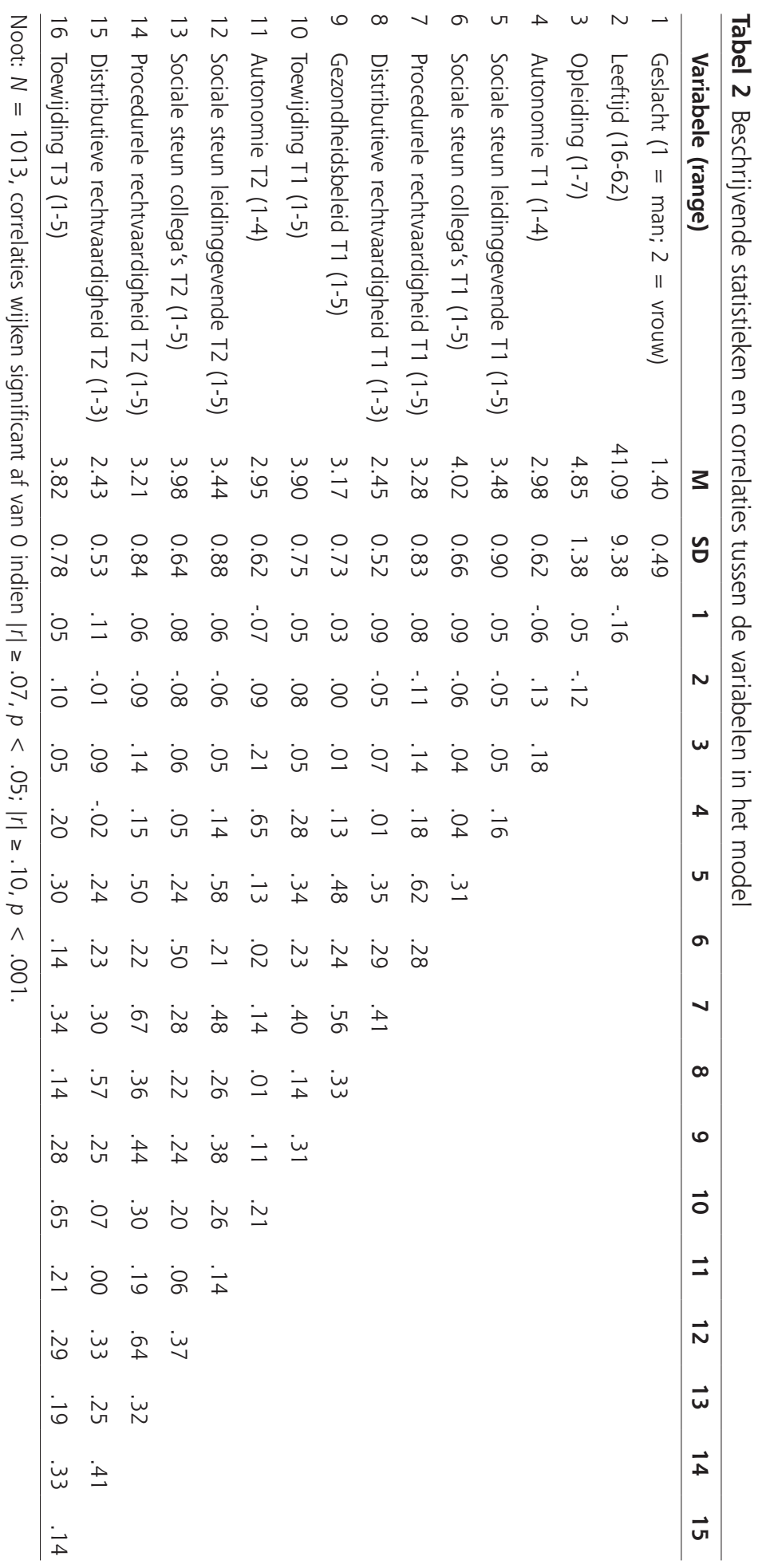


Tabel 3 Effecten van gezondheidsbeleid op T1 op hulpbronnen (autonomie, sociale steun en rechtvaardigheid) op T2, met gestandaardiseerde regressiegewichten $(\beta)$

\begin{tabular}{lccccc}
\hline & $\begin{array}{l}\text { Autonomie } \\
\text { T2 }\end{array}$ & $\begin{array}{l}\text { Sociale steun } \\
\text { leiding- } \\
\text { gevende T2 }\end{array}$ & $\begin{array}{l}\text { Sociale steun } \\
\text { collega's T2 }\end{array}$ & $\begin{array}{l}\text { Procedurele } \\
\text { rechtvaardig- } \\
\text { heid T2 }\end{array}$ & $\begin{array}{l}\text { Distributieve } \\
\text { rechtvaardig- } \\
\text { heid T2 }\end{array}$ \\
\hline Geslacht & -.031 & .021 & .024 & -.004 & $.067^{*}$ \\
Leeftijd & .018 & -.028 & -.049 & -.019 & .036 \\
Opleiding & $.106^{* * *}$ & .021 & .034 & $.050^{*}$ & $.054^{*}$ \\
Autonomie T1 & $.620^{* *}$ & & & & \\
$\begin{array}{l}\text { Sociale steun lei- } \\
\text { dinggevende T1 }\end{array}$ & & $.510^{* * *}$ & & & \\
$\begin{array}{l}\text { Sociale steun } \\
\text { collega's T1 }\end{array}$ & & & & & \\
$\begin{array}{l}\text { Procedurele } \\
\text { rechtvaardig- } \\
\text { heid T1 }\end{array}$ \\
$\begin{array}{l}\text { Distributieve } \\
\text { rechtvaardig- }\end{array}$ \\
heid T1 \\
$\begin{array}{l}\text { Gezondheids- } \\
\text { beleid T1 }\end{array}$ \\
\hline
\end{tabular}

Noot: $N=1013^{*} p<.05,{ }^{* *} p<.01,{ }^{* *} p<.001$

\subsection{Effecten van gezondheidsbeleid op toewijding}

Vervolgens is de invloed van gezondheidsbeleid op toewijding onderzocht in een hiërarchische regressieanalyse, die is weergegeven in tabel 4 . In de eerste stap van de regressie van toewijding op $\mathrm{T}_{3}$ is toewijding op $\mathrm{T}_{\mathrm{I}}$ en geslacht, leeftijd en opleidingsniveau zoals gemeten op $T_{I}$, ingevoerd. In de tweede stap is gezondheidsbeleid op $T_{I}$ ingevoerd. Met deze stap wordt hypothese I getoetst. In de derde stap van de regressie wordt autonomie gemeten op $\mathrm{T}_{2}$ ingevoerd. In de vierde stap worden sociale steun van de leidinggevende en van collega's gemeten op $\mathrm{T}_{2}$ ingevoerd. Ten slotte wordt in de vijfde stap de distributieve en procedurele rechtvaardigheid gemeten op $\mathrm{T}_{2}$ ingevoerd in de regressie. De hulpbronnen worden in deze volgorde ingevoerd in de regressievergelijking omdat er een zekere hiërarchie bestaat tussen deze hulpbronnen. Autonomie betreft de werkinhoud van het individu, sociale steun het sociale klimaat in het team (leidinggevende en collega's) en rechtvaardigheid de bredere organisatiecultuur. Hypothese 3 wordt getoetst in deze derde tot vijfde stap van de regressie.

Uit stap I blijkt dat de toewijding op TI sterk van invloed is op de toewijding op $T_{3}$. Werknemers die toegewijd zijn op de eerste meting, zijn doorgaans ook toegewijd op de derde meting. Tevens blijkt dat de leeftijd bijdraagt aan de toewijding op $\mathrm{T}_{3}$. Naarmate men ouder is, wordt men meer toegewijd.

Uit de tweede stap van de regressieanalyse blijkt, in overeenstemming met hypothese I, dat een hoge score op gezondheidsbeleid op $\mathrm{T}_{\mathrm{I}}$ leidt tot meer toewijding op $\mathrm{T}_{3}$. 
Daarbij is gecorrigeerd voor de toewijding op TI, waardoor kan worden geconcludeerd dat goed gezondheidsbeleid de toewijding van werknemers vergroot.

In de derde stap van de regressieanalyse is onderzocht of autonomie van invloed is op de toewijding. In overeenstemming met hypothese 3 blijkt uit de analyse dat ervaren autonomie leidt tot een hogere toewijding. In de vierde stap zijn sociale steun van de leidinggevende en sociale steun van collega's ingevoerd in de regressie van toewijding. Hier blijkt dat sociale steun van de leidinggevende bijdraagt aan hogere toewijding, terwijl sociale steun van collega's geen invloed heeft. Ten slotte worden procedurele en distributieve rechtvaardigheid opgenomen in de analyse. Uit deze analyse blijkt dat procedurele rechtvaardigheid de toewijding van werknemers vergroot, terwijl distributieve rechtvaardigheid hierop geen invloed heeft. Tevens blijkt dat na invoering van procedurele en distributieve rechtvaardigheid in het regressiemodel, gezondheidsbeleid niet langer significant bijdraagt aan de voorspelling van de 364 toewijding van werknemers. Ook het effect van sociale steun van de leidinggevende op toewijding neemt af wanneer procedurele en distributieve rechtvaardigheid in het model worden meegenomen. In overeenstemming met hypothese 3 dragen de hulpbronnen dus bij aan de toewijding van werknemers. Dit geldt voor autonomie, sociale steun van leidinggevende en procedurele rechtvaardigheid, maar niet voor sociale steun van collega's en distributieve rechtvaardigheid.

Tabel 4 Resultaten van de regressieanalyse van toewijding op T3 met gestandaardiseerde regressiegewichten ( $\beta$ )

\begin{tabular}{llllll}
\hline & Stap 1 & Stap 2 & Stap 3 & Stap 4 & Stap 5 \\
\hline Toewijding (T1) & $.640^{* * *}$ & $.611^{* * *}$ & $.599^{* * *}$ & $.580^{* * *}$ & $.575^{* * *}$ \\
Geslacht (T1) & .026 & .025 & .030 & .025 & .022 \\
Leeftijd (T1) & $.059^{*}$ & $.061^{*}$ & $.055^{*}$ & $.065^{* *}$ & $.068^{* *}$ \\
Opleiding (T1) & .028 & .029 & .015 & .012 & .002 \\
Gezondheidsbeleid (T1) & & $.096^{* * *}$ & $.092^{* * *}$ & $.053^{*}$ & .030 \\
Autonomie (T2) & & $.066^{* *}$ & $.058^{*}$ & $.054^{*}$ \\
Sociale steun leidingge- & & & $.106^{* *}$ & $.056^{+}$ \\
vende (T2) & & & & .026 \\
Sociale steun collega's (T2) & & & & .018 \\
Procedurele rechtvaardig- & & & & $.086^{*}$ \\
heid (T2) & & & & .029 \\
Distributieve rechtvaardig- & & & & \\
heid (T2)
\end{tabular}

Noot: $N=1013, R^{2}=.452,+p<.10,{ }^{*} p<.05,{ }^{* *} p<.01, * * * p<.001$

In de uiteindelijke regressieanalyse dragen een hogere leeftijd, meer autonomie, meer sociale steun van de leidinggevende (marginaal significant) en meer procedurele rechtvaardigheid bij aan een toename van toewijding van $T_{1}$ naar $T_{3}$. De indirecte effecten van gezondheidsbeleid op toewijding zijn getoetst met de Sobel-test. Het onderzoeksmodel met de directe en indirecte effecten van gezondheidsbeleid zijn

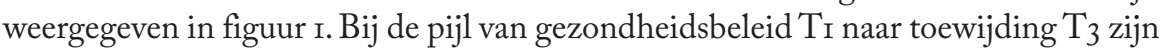


het directe effect en (tussen haakjes) het totale effect van gezondheidsbeleid Ti op toewijding $\mathrm{T}_{3}$ gegeven. Beide effecten zijn gecorrigeerd voor toewijding $\mathrm{T}_{\mathrm{r}}$, geslacht, leeftijd en opleidingsniveau. Het directe effect is bovendien gecorrigeerd voor autonomie, sociale steun en rechtvaardigheid op $\mathrm{T}_{2}$. Uit figuur I blijkt dat het effect van gezondheidsbeleid op toewijding gedeeltelijk loopt via sociale steun van de leidinggevende en procedurele rechtvaardigheid. Een hoge score op gezondheidsbeleid op TI leidt tot een toename van sociale steun van de leidinggevende en tot meer procedurele rechtvaardigheid op $T_{2}$. Vervolgens leiden sociale steun van leidinggevenden en procedurele rechtvaardigheid op $T_{2}$ tot een hogere toewijding op $T_{3}$. Hiermee wordt hypothese 4 bevestigd.

T1

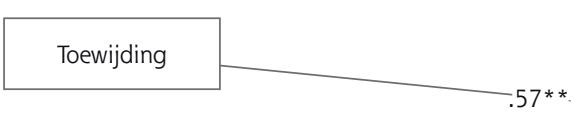

T3

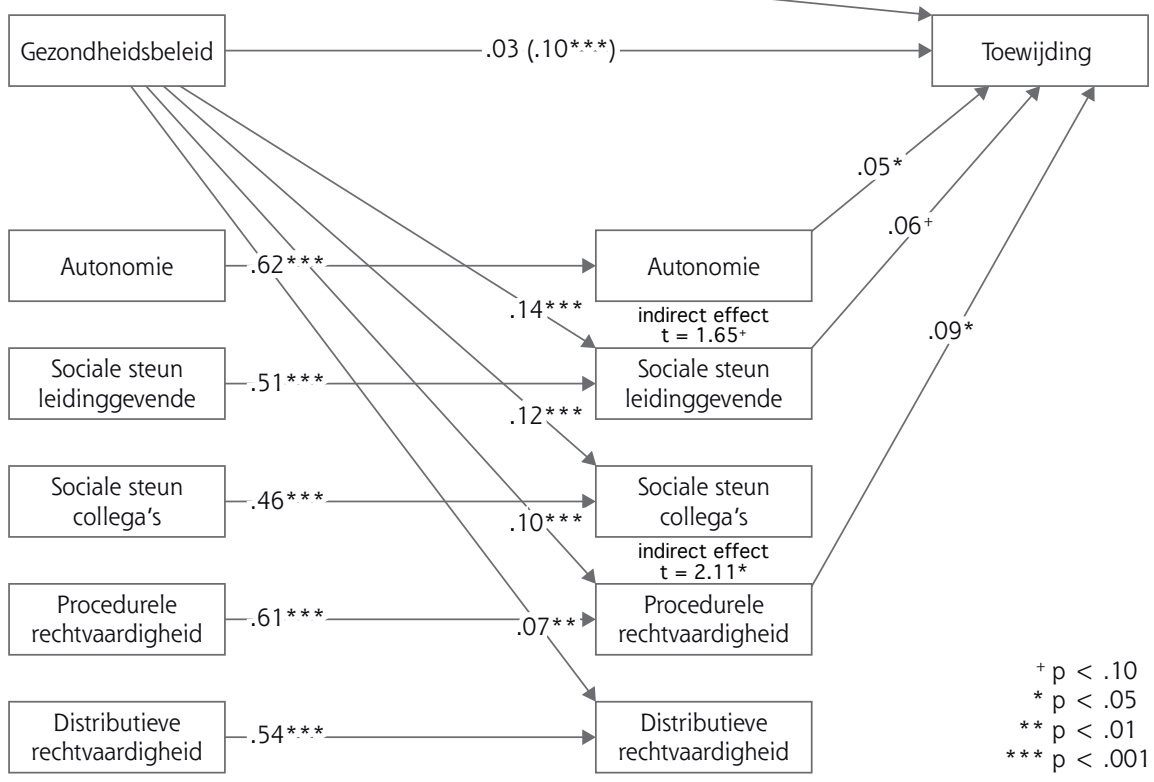

Figuur 1 Het effect van gezondheidsbeleid op toewijding via autonomie, sociale steun en rechtvaardigheid

\section{Discussie}

In deze studie is onderzocht wat het effect is van gezondheidsbeleid op de toewijding van werknemers en hoe dit effect tot stand komt. In overeenstemming met de hypothese blijkt uit het onderzoek dat werknemers die rapporteren dat hun bedrijf veel investeert in gezondheidsbeleid, twee jaar later meer toegewijd zijn. Gezondheidsbeleid bevordert dus de toewijding van werknemers. Daarnaast werpt dit onderzoek licht 
op de processen die ten grondslag liggen aan dit positieve effect van gezondheidsbeleid. In overeenstemming met de hypothese leidt gezondheidsbeleid tot meer hulpbronnen in het werk en - gedeeltelijk via die hulpbronnen - tot meer toewijding. Meer specifiek leidt gezondheidsbeleid tot meer sociale steun van leidinggevende en collega's en tot meer procedurele en distributieve rechtvaardigheid. De effecten van gezondheidsbeleid op toewijding worden gedeeltelijk gemedieerd door de toename in sociale steun van de leidinggevende en in procedurele rechtvaardigheid.

In lijn met het Job Demands-Resources (JD-R)-model en met eerdere studies blijken autonomie en sociale steun van leidinggevende te fungeren als hulpbronnen in het werk, die een positief effect hebben op de toewijding van werknemers één jaar later (Hakanen et al., 2006; Saks, 2006; Xanthopoulou et al., 2007). Daarnaast vinden we in lijn met onze hypothese dat ook procedurele rechtvaardigheid één jaar later leidt tot meer toewijding. Deze bevinding impliceert dat ook de organisatiecultuur een 366 hulpbron kan vormen voor werknemers. Dit onderzoek ondersteunt daarmee het motivatieproces zoals beschreven door het JD-R-model. Een belangrijke implicatie van ons onderzoek is bovendien dat de hulpbronnen sociale steun en rechtvaardigheid vergroot kunnen worden door het gezondheidsbeleid van de organisatie.

In dit onderzoek hebben we gezondheidsbeleid gemeten met een schaal die is gebaseerd op Integraal Gezondheidsmanagement (IGM). IGM is in het leven geroepen als reactie op de versnipperde initiatieven en interventies die gericht zijn op het bevorderen van de gezondheid van werknemers in een organisatie. In ons onderzoek heeft gezondheidsbeleid geen directe effecten op de autonomie, maar wel op het sociale klimaat in de organisatie en op een gezonde organisatiecultuur, die gekenmerkt worden door veel sociale steun van de leidinggevende en collega's en door veel rechtvaardigheid in de organisatie. Deze resultaten suggereren dat een integrale aanpak van gezondheid effectief is. Integraal gezondheidsbeleid maakt hulpbronnen vrij die op hun beurt de toewijding van werknemers vergroten. Op basis van onze bevindingen kunnen we echter niet achterhalen in hoeverre we erin zijn geslaagd om het integrale aspect van IGM te meten. Het lijkt echter onwaarschijnlijk dat versnipperde gezondheidsmaatregelen zulke substantiële effecten op hulpbronnen en toewijding zouden sorteren.

Naast een wetenschappelijk belang heeft de studie hiermee tevens implicaties voor de praktijk. Dit onderzoek benadrukt het belang van een integrale gezondheidsaanpak voor de toewijding van werknemers. Goed gezondheidsbeleid zou daarom een centrale doelstelling voor organisaties moeten zijn, omdat dit de hulpbronnen en toewijding van werknemers bevordert. Andere auteurs benadrukken dat gezondheidsbeleid economische waarde kan hebben in de vorm van minder ziektekosten en een hogere productiviteit (Johanson e.a., 2007, Zwetsloot \& van Scheppingen 2007).

Gezondheidsbeleid zou moeten zijn gericht op een breed scala van factoren. Deze studie toont aan dat investeren in het verhogen van de autonomie en het vergroten van sociale steun van de leidinggevende een positieve werking hebben op de toewijding van werknemers. Maar ook het investeren in een gezonde organisatiecultuur waarin rechtvaardigheid hoog in het vaandel staat, blijkt een positief effect te hebben op de toewijding. Met deze bevindingen kunnen bedrijven die de toewijding van werknemers willen verhogen, hun gezondheidsbeleid aanscherpen door te investeren 
in de autonomie, de sociale steun van leidinggevenden en in procedurele rechtvaardigheid in de organisatie.

De hier beschreven studie heeft diverse sterke punten. Ten eerste maakt deze studie gebuik van longitudinale data met drie metingen. Hierdoor is het mogelijk om de onafhankelijke variabele ( $\mathrm{T}_{\mathrm{I}}$ gezondheidsbeleid), mediatoren ( $\mathrm{T}_{2}$ autonomie, sociale steun en rechtvaardigheid) en afhankelijke variabele ( $\mathrm{T}_{3}$ toewijding) in de tijd uit elkaar te trekken, waardoor mediatie op een optimale wijze getoetst kan worden. Bovendien wordt daarbij gecorrigeerd voor toewijding en mediatoren op de eerste meting, waardoor de longitudinale effecten van gezondheidsbeleid met meer zekerheid causaal geïnterpreteerd kunnen worden. Bovendien maakt het onderzoek gebruik van een omvangrijke, heterogene steekproef, welke min of meer representatief is voor de werknemerspopulatie in Nederland. Dit maakt het mogelijk generaliserende uitspraken te doen over de populatie werknemers in Nederland.

Toch zijn er ook enkele kanttekeningen te maken bij deze studie. In deze studie zijn individuele werknemers gevraagd naar hun oordeel over het gezondheidsbeleid in hun organisatie. Het is onduidelijk in hoeverre dit oordeel overeenkomt met dat van hun collega's, leidinggevenden of management. Om dit te onderzoeken zou in een steekproef van bedrijven zowel het management als meerdere werknemers uit diverse lagen van de organisatie gevraagd kunnen worden naar hun oordeel over het gezondheidsbeleid. Een interessante vraag daarbij is dan in welke mate het gedeelde oordeel over het gezondheidsbeleid (op bedrijfsniveau), dan wel de individuele verschillen in dit oordeel (op werknemersniveau) sturend zijn voor de toewijding en gezondheid van werknemers.

Bovendien is in dit onderzoek de status quo in het gezondheidsbeleid van de organisatie gemeten. Op basis van dit onderzoek kunnen daarom geen uitspraken worden gedaan over de effecten van een organisatieverandering waarin integraal gezondheidsbeleid wordt ingevoerd. Daarvoor is quasi-experimenteel onderzoek nodig onder bedrijven waarvan de helft dergelijk gezondheidsbeleid invoert en de andere helft niet.

Ten slotte is het goed om stil te staan bij de grootte van de longitudinale effecten van gezondheidsbeleid op toewijding en op hulpbronnen en van hulpbronnen op toewijding. Dit lijken kleine effecten te zijn. Hierbij is het echter van belang om te bedenken dat deze effecten gecorrigeerd zijn voor de eerdere metingen van de betreffende afhankelijke variabele. Bijvoorbeeld het effect van gezondheidsbeleid op sociale steun van de leidinggevende is gecorrigeerd voor de sociale steun van de leidinggevende een jaar eerder. Doordat de hulpbronnen en toewijding een behoorlijke stabiliteit kennen, is het te verwachten effect van andere variabelen klein. Het feit dat we desondanks de voorspelde longitudinale effecten vinden, onderstreept het belang van gezondheidsbeleid voor hulpbronnen en het belang van gezondheidsbeleid en hulpbronnen voor toewijding van werknemers.

Ondanks deze kanttekeningen levert het onderzoek interessante nieuwe inzichten op in de effecten en de werking van gezondheidsbeleid. Deze studie draagt bij aan het vergroten van het inzicht in het effect van gezondheidsbeleid op toewijding en de processen die hieraan ten grondslag liggen. Uit het onderzoek blijkt dat gezondheidsbeleid de toewijding van werknemers vergroot en dat dit effect gedeeltelijk loopt via hogere sociale steun van leidinggevenden en hogere procedurele rechtvaardigheid. 
Dit onderzoek heeft hiermee niet alleen wetenschappelijke waarde, maar ook belangrijke implicaties voor de praktijk. Bedrijven die de toewijding van werknemers willen vergroten, doen er goed aan om te investeren in integraal gezondheidsbeleid. Dit betekent dat gezondheid een centrale waarde in het bedrijf inneemt, wat zich vertaalt in een goed sociaal klimaat en in rechtvaardigheid in de organisatie.

\section{Praktijkbox}

Wat betekenen de resultaten voor de praktijk?

- Door goed gezondheidsbeleid te voeren, kunnen organisaties de toewijding van werknemers bevorderen.

- Goed gezondheidsbeleid leidt tot meer sociale steun en meer rechtvaardigheid in de organisatie.

- Organisaties kunnen de toewijding van werknemers vergroten door werknemers veel autonomie te geven, door veel sociale steun van leidinggevenden en door rechtvaardige procedures in de organisatie.

\section{Literatuur}

Adams, J.S. (1965). Inequity in social exchange. In L. Berkowitz (Ed.), Advances in experimental social psychology, Vol. 2 (pp. 267-299). New York: Academic Press.

Aust, B. \& Ducki, A. (2004). Comprehensive health promotion interventions at the workplace: Experiences with health circles in Germany. Journal of Occupational Health Psychology, 9, 258-270.

Baron, R.M. \& Kenny, D.A. (1986). The moderator-mediator variable distinction in social psychological research: Conceptual, strategic, and statistical considerations. Journal of Personality and Social Psychology, 5I, II73-II82.

Cohen, S. \& Wills, T.A. (1985). Stress, social support, and the buffering hypothesis. Psychological Bulletin, 98, 310-357.

Cole, D.A. \& Maxwell, S.E. (2003). Testing mediational models with longitudinal data: Questions and tips in the use of structural equation modeling. Journal of Abnormal Psychology, II2, 558-577.

Cropanzano, R. \& Greenberg, J. (1997). Progress in organizational justice: Tunneling through the maze. In C.I. Cooper \& I.T. Robertson (Eds.), International Review of Industrial and Organizational Psychology, Vol. I2 (pp. 317-372). Chichester: Wiley.

De Boer, E.M., Bakker, A.B., Syroit, J.E. \& Schaufeli, W.B. (2002). Unfairness at work as a predictor of absenteeism. Journal of Organizational Behavior, 23, I8I-197.

Demerouti, E., Bakker, A.B., Nachreiner, F. \& Schaufeli, W.B. (200I). The Job DemandsResources model of burnout. Journal of Applied Psychology, 86, 499-512.

Goetzel, R.Z., Ozminkowski, R.J., Bowen, J. \& Tabrizi, M.J. (2008). Employer integration of health promotion and health protection programs. International Journal of Workplace Health Management, I, Io9-I22.

Goetzel, R.Z., Shechter, D., Marmet, P.Z.F., Tabrizi, M.J. \& Roemer, E.C., (2007). Promising practice in employer health and productivity management efforts: findings from a benchmarking study. Journal of Occupational and Environmental Medicine, 49, III-I3O.

Greenberg, J. \& Colquitt, J.A. (Eds.) (2005). Handbook of Organizational Justice. Mahwah, NJ: Erlbaum. 
Gründemann, R., Piek, P., Zwetsloot, G., Van Scheppingen, A., Raaijmakers, T. \& Vaandrager, L. (2003). Integraal Gezondheidsmanagement; methodiek in ontwikkeling. Hoofddorp: TNO Arbeid.

Hakanen, J., Bakker, A.B. \& Schaufeli, W. B. (2006). Burnout and work engagement among teachers. Journal of School Psychology, 43, 495-513.

Halbesleben, J.R.B. (2006). Sources of social support and burnout: A meta-analytic test of the Conservation of Resources Model. Journal of Applied Psychology, 9I, II34-II45.

Hasle, P. \& Møller, N. (2007). From conflict to shared development: Social capital in a Tayloristic environment. Economic and Industrial Democracy, 28, 40I-429.

Hobfoll, S.E. (1989). Conservation of resources: A new attempt at conceptualizing stress. American Psychologist, 44, 513-524.

Johanson, U., Ahonen, G. \& Roslender, R. (Eds.) (2007). Work Health and Management Control. Stockholm: Thomson Fakta.

Karasek, R., Brisson, Ch., Kawakami, N., Houtman, I., Bongers, P. \& Amick, B. (I998). The Job Content Questionnaire (JCQ): an instrument for international comparative assessments of psychological job characteristics. Journal of Occupational Health Psychology, 3, I998, pp. 322-355.

Mauno, S., Kinnunen, U. \& Ruokolainen, M. (2007). Job demands and resources as antecedents of work engagement: A longitudinal study. Journal of Vocational Behavior, 70, I49-I7I.

Ouweneel, E., Schaufeli, W. \& Le Blanc, P. (2009). Van preventie naar amplitie: interventies voor optimaal functioneren. Gedrag \& Organisatie, 22, II8-I35.

Saks, A. M. (2006). Antecedents and consequences of employee engagement. Journal of Managerial Psychology, 2I, 600-66r.

Schaufeli, W. \& Bakker, A.B. (200I). Werk en welbevinden: Naar een positieve benadering in de Arbeids- en Gezondheidspsychologie. Gedrag E Organisatie,I4, 229-253.

Schaufeli, W. \& Bakker, A.B. (2004). Bevlogenheid: een begrip gemeten. Gedrag \& Organisatie, I7, 89-II2.

Schaufeli, W.B., Salanova, M., Gonzáles-Romá, V. \& Bakker, A.B. (2002). The measurement of engagement and burnout: A two sample confirmatory factor analytic approach. Journal of Happiness Studies, 3, pp. 71-92.

Shain, M. \& Kramer, D. M. (2004). Health promotion in the workplace: framing the concept, reviewing the evidence. Journal of Occupational and Environmental Medicine, 6r, $643-648$.

Sorensen, G. \& Barbeau, E. (2004). Steps to a Healthier US Workforce: Integrating Occupational Health and Safety and Worksite Health Promotion: State of the Science. Commissioned paper for Steps to a Healthier US Workforce Symposium Oct. 26-2,8 2004. Washington, DC: The National Institute of Occupational Safety and Health (NIOSH).

Visser, F. \& Witte, K.E. (2005). Effectiviteit. In: Brancherapporten VWS: De VWS-sectoren Preventie - Feiten en ciffers - Settinggerichte preventie - Werkplek. Den Haag: VWS.

Xanthopoulou, D., Bakker, A.B., Demerouti, E. \& Schaufeli, W.B. (2007). The role of personal resources in the job demands-resources model. International Journal of Stress Management, I4, I2I-I4I.

Ybema, J.F. (2007). De invloed van rechtvaardigheid op werkuitkomsten: een longitudinaal perspectief. Gedrag E Organisatie, 20, 409-426.

Ybema, J.F., Sanders, J. \& De Vroome, E. (2006). Cohortstudie Arbeid, Verzuim en Gezondheid $(A V G)$ : Methodologie en eerste resultaten 2004-2006. Hoofddorp: TNO.

Zwetsloot, G. \& Pot, F. (2004). The business value of health management. Journal of Business Ethics, 55, II5-I24.

Zwetsloot, G.I.J.M. \& Van Scheppingen, A. (2007). Towards a strategic business case for health management. In: U. Johanson, G. Ahonen \& R. Roslender (Eds.), Work Health and Management Control (pp I83-213). Stockholm: Thomson Fakta. 


\section{How health policy influences the dedication of employees}

J.F. Ybema \& M. Bakhuys Roozeboom, Gedrag \& Organisatie, volume 22, November 2009, nr. 4, pp. 354-370.

A longitudinal study with three yearly waves of data collection among 1.013 employees was used to examine whether employers' health policy improved dedication of employees. Furthermore, it was examined whether health policy improved autonomy, social support (from supervisor, from colleagues), and organizational justice (procedural, distributive), and whether health policy affects dedication through these job resources. The results showed that health policy at T1 contributed to higher dedication at T3, corrected for dedication at T1. Moreover, health policy did not improve autonomy, but it led to more social support from supervisor and colleagues and to more procedural and distributive justice at T2, corrected for these job resources at $\mathrm{T} 1$. The effects of health policy on dedication were partly mediated by more social support from the supervisor and by higher procedural justice. This means that employers should invest in health policy to improve the job resources and dedication of employees.

Key words: health policy, dedication, resources, longitudinal research 